\title{
Linkages between coral assemblages and coral proxies of terrestrial exposure along a cross-shelf gradient on the southern Great Barrier Reef
}

\author{
S. Jupiter - G. Roff - G. Marion - M. Henderson • \\ V. Schrameyer $\cdot$ M. McCulloch $\cdot$ O. Hoegh-Guldberg
}

Received: 27 March 2008/ Accepted: 26 August 2008/Published online: 13 September 2008

(c) Springer-Verlag 2008

\begin{abstract}
Coral core records, combined with measurements of coral community structure, were used to assess the long-term impact of multiple environmental stressors on reef assemblages along an environmental gradient. Multiple proxies (luminescent lines, $\mathrm{Ba} / \mathrm{Ca}, \delta^{15} \mathrm{~N}$ ) that reflect different environmental conditions (freshwater discharge, sediment delivery to the nearshore, nutrient availability and transformations) were measured in Porites coral cores collected from nearshore reefs at increasing distance from the intensively agricultural region of Mackay (Queensland, Australia). The corals provide a record (1968-2002) of the frequency and intensity of exposure to terrestrial runoff and fertilizer-derived nitrogen and were used to assess how the present-day coral community composition may have been influenced by flood-related disturbance. Reefs closest to the mainland (5-32 km offshore) were characterized by low
\end{abstract}

Communicated by Environment Editor Prof. Rob van Woesik

S. Jupiter · M. McCulloch

ARC Centre of Excellence for Coral Reef Studies,

The Australian National University, Canberra, ACT 0200,

Australia

S. Jupiter

Australian Institute of Marine Science, PMB \#3, Townsville

MC, QLD 4810, Australia

S. Jupiter · G. Roff · G. Marion · M. Henderson

V. Schrameyer · O. Hoegh-Guldberg

ARC Centre of Excellence for Coral Reef Studies, Centre for

Marine Studies, The University of Queensland, Brisbane,

QLD 4072, Australia

S. Jupiter $(\square)$

WCS South Pacific Country Program, 11 Ma'afu Street, Suva, Fiji Islands

e-mail: sjupiter@wcs.org hard coral cover $(\leq 10 \%)$, with no significant differences among locations. Distinct annual luminescent lines and elevated $\mathrm{Ba} / \mathrm{Ca}$ values $\quad\left(4.98 \pm 0.63 \mu \mathrm{mol} \mathrm{mol}{ }^{-1}\right.$; mean $\pm \mathrm{SD}$ ) in the most inshore corals (Round Top Island; $5 \mathrm{~km}$ offshore) indicated chronic, sub-annual exposure to freshwater and resuspended terrestrial sediment that may have historically prevented reef formation. By contrast, corals from Keswick Island (32 km offshore) indicated episodic, high-magnitude exposure to Pioneer River discharge during extreme flood events (e.g., 1974, 1991), with strongly luminescent lines and substantially enriched coral skeletal $\delta^{15} \mathrm{~N}(12-14 \%)$. The reef assemblages at Keswick and St. Bees islands were categorically different from all other locations, with high fleshy macroalgal cover $(80.1 \pm 7.2 \%$ and $62.7 \pm 7.1 \%$, respective mean $\pm \mathrm{SE})$ overgrowing dead reef matrix. Coral records from Scawfell Island (51 km offshore) indicated little exposure to Pioneer catchment influence: all locations from Scawfell and further offshore had total hard and soft coral cover comparable to largely undisturbed nearshore to middle shelf reefs of the southern Great Barrier Reef.

Keywords Porites - Luminescence - Barium · Nitrogen isotope $\cdot$ Coral assemblage .

Disturbance frequency

\section{Introduction}

There is growing concern that rapid rates of global environmental change are increasing the frequency and severity of disturbance (e.g., tropical cyclones, bleaching) to coral reefs (Nystrom et al. 2000; Hoegh-Guldberg et al. 2007). While intermediate levels of disturbance maintain high diversity on coral reefs (Connell 1978), high levels of 
disturbance can cause community changes through the removal of local species (DeVantier et al. 2006) or via shifts to alternate states (Hughes 1994). Nearshore reefs adjacent to highly modified catchments may be particularly vulnerable to ecological shifts of this nature if chronically degraded water quality acts to reduce resilience to extreme disturbances (McCook 1999).

Long-term coral reef monitoring records can distinguish coral community responses to both natural and anthropogenic disturbance. For example, Done et al. (2007) used $>20$ years of photography and videography to study community dynamics at the chronically disturbed, turbid and nearshore Pandora Reef on the central Great Barrier Reef (GBR). They found that while recovery trajectories from tropical cyclone, flood, and heat wave disturbances varied by reef zone, the main limits to recovery of coral populations were reduced supply of coral brood stock and increased frequency of climate-related disturbances (Done et al. 2007). Despite their usefulness, long-term data sets like these are rare, particularly at high enough temporal resolution to capture rapid transitions in direct response to specific disturbances (Ostrander et al. 2000).

In the absence of long-term monitoring data, several different methods have been employed in separate regions of the GBR to assess whether nearshore reefs have experienced recent degradation. When Fabricius et al. (2005) compared community characteristics from nearshore reefs adjacent to the highly agricultural Wet Tropics catchments and the less modified Princess Charlotte Bay catchments, they found three response variables (macroalgal cover, octocoral richness, abundance of sensitive hard coral species) that were significantly correlated with a water quality index constructed from twelve water quality variables sampled repeatedly at each reef. The study shows a strong link between present day ecological community structure and recent water quality, supported by modeling studies which indicate long-term increases in sediment and nutrient delivery to the Wet Tropics region (Neil et al. 2002; Wooldridge et al. 2006).

A different approach is to determine whether a mismatch exists between present reef-building capacity and Holocene reef framework along a distance gradient from a river source (van Woesik et al. 1999). van Woesik et al. (1999) suggested that the limited reef-building at Calf and Pine islands in the Whitsunday Group of the southern GBR was associated with recent increases in suspended particulate matter and nutrients delivered to Repulse Bay by the Proserpine and O'Connell rivers. This hypothesis is likely given the rapid agricultural expansion in the Proserpine and O'Connell catchments during the past 150 years (Pulsford 1996) and measured high levels of chlorophyll $a$ and sediment nitrogen at reefs closest to river sources (van Woesik et al. 1999). However, changes on longer temporal scales, such as the closure of the Holocene high-energy window which reduced flushing from Repulse Bay, may have also contributed to reduce carbonate accretion (Hopley 1984).

In this study, a novel approach to assess broad differences in community structure is presented which links present-day coral assemblages with disturbance histories inferred from biogeochemical signatures measured from coral cores collected along a distance gradient adjacent to a highly agricultural region of the southern GBR. Three types of proxy records were derived from massive Porites coral colonies and were used to investigate the frequency and intensity of exposure to terrestrial discharge and fertilizer-derived nitrogen. Firstly, luminescent lines from nearshore corals on the GBR are strongly related to river discharge events (Isdale 1984; Lough et al. 2002). Secondly, peaks in barium to calcium ratios $(\mathrm{Ba} / \mathrm{Ca})$ coincide with episodic release of sediments discharged to the nearshore environment by flood events from large, dry catchments (McCulloch et al. 2003). The last proxy, coral skeletal $\delta^{15} \mathrm{~N}$, provides time-integrated measurements of relative nutrient availability bearing a signature that can be traced back to anthropogenic nitrogen sources within the catchment (Marion et al. 2005; Marion 2007). These records are combined with data on regional climate perturbations to assess recurrence intervals of disturbance since the late 1970s at three nearshore reefs. Because longlived massive Porites are less susceptible to mortality from bleaching, mechanical injury and predation by COTS than faster growing species, such as acroporids (De'ath and Moran 1998; Marshall and Baird 2000), strong responses recorded in Porites skeletons can be indicators of largescale disturbances that could affect survivorship of less robust corals.

The two primary objectives in this study were to: (1) describe the present-day coral community composition along a cross-shelf gradient on the southern GBR; and (2) assess the frequency and intensity with which the nearshore reefs are exposed to terrestrial runoff that might inhibit coral recovery from large-scale disturbance.

\section{Materials and methods}

\section{Study region}

The study focused on a transect of reefs fringing continental islands (Round Top: $5 \mathrm{~km}$ offshore, Keswick: $32 \mathrm{~km}$, St Bees: $32 \mathrm{~km}$, Scawfell: $51 \mathrm{~km}$, and Derwent: $61 \mathrm{~km}$ ) or carbonate platforms (Big Kindemar: $127 \mathrm{~km}$ and Little Kindemar: 123-134 km) along a distance gradient from the Pioneer River drainage and city of Mackay in the Mackay Whitsunday region of the southern GBR (Fig. 1). Although the catchments of the Mackay Whitsunday 
region (Proserpine, O'Connell, Pioneer and Plane) represent only a small proportion $(2.1 \%)$ of the $423,070 \mathrm{~km}^{2}$ terrestrial area draining into the GBR World Heritage

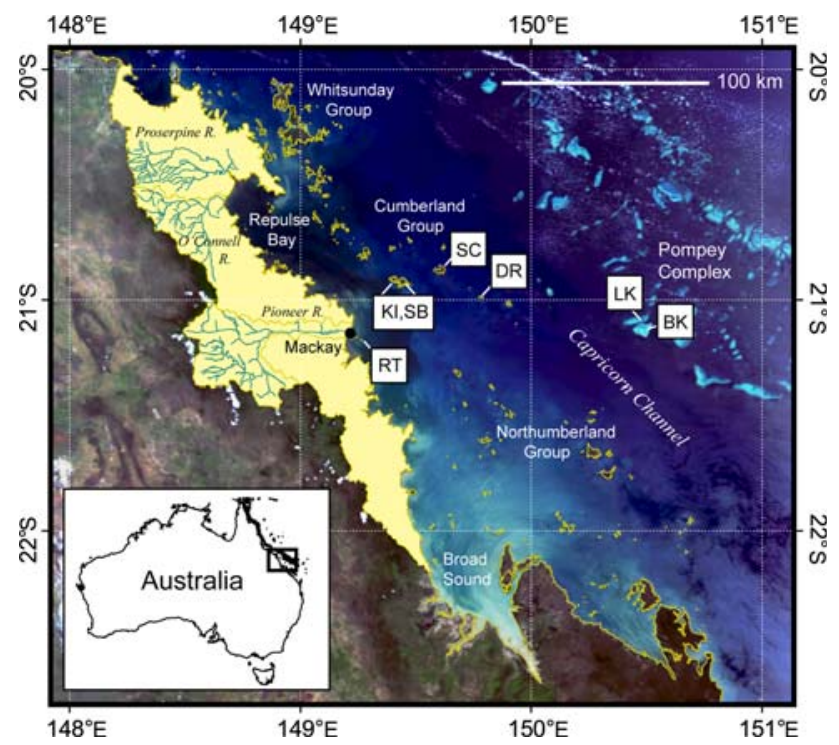

Fig. 1 Locations of coral coring and ecological survey locations within the Mackay region of the southern Great Barrier Reef. RT, Round Top Island; KI, Keswick Island; SB, St. Bees Island; SC, Scawfell Island; DR, Derwent Island; LK, Little Kindemar Reef; BK, Big Kindemar Reef. Yellow regions are catchments of the Mackay Whitsunday management area overlaid with three major drainages. Map is displayed on a subset of a MODIS Terra satellite image (courtesy of NASA/GSFC - http://ladsweb.nascom.nasa.gov/data/), captured 28 January 2005 following a minor flooding event. The inset depicts the location of the study region within Australia on the central Queensland coast
Area, $\sim 79 \%$ of the region is occupied by intensive agriculture or grazing (Rayment and Neil 1997).

Regional precipitation and river flow in northeast Queensland are strongly influenced by El Niño-Southern Oscillation (ENSO) events (Lough 1994). Mackay's tropical, humid climate exhibits seasonal wet/dry variability, with $\sim 75 \%$ of rain falling between the austral summer months of October and March. As a consequence, Pioneer River flow is highly episodic: floods accounted for $89 \pm 8 \%$ of freshwater discharged annually (mean \pm SD for composite record spanning 1916 to 2003 from Queensland Department of Natural Resources and Water stations 125001A and 125007A). Strong prevailing southeasterly winds, such as observed at Mackay, produce longshore movement of inner shelf waters that typically cause northward spreading of flood plumes (King et al. 2001). Since 1968, there were 9 years with distinct, highmagnitude Pioneer River discharge events, eight tropical cyclones within the vicinity of Mackay, and three periods of high or prolonged positive sea surface temperature (SST) anomalies associated with known ENSO events (Fig. 2).

\section{Ecological surveys}

During March 2006, photoquadrat surveys were undertaken along 20 transects at shallow depths (1-5 m below Lowest Astronomical Tide (LAT)), parallel to the reef flat to assess coral family assemblages and benthic cover at each of the reefs. A minimum of two sites were surveyed at each reef,
Fig. 2 Records of regional climatic perturbations (tropical cyclones, sea surface temperature (SST) anomalies) and Pioneer River discharge. SST anomalies were calculated using weekly means from IGOSS regional $1^{\circ}$ gridded weekly SST records, November 1981-December 2004.

Cyclones are listed with closest proximity date to Mackay and maximum associated wind speed at Mackay, Australian Bureau of Meteorology station 33119. Dashed vertical lines show elevated discharge associated with cyclones. Solid vertical lines show periods of sustained, positive SST anomalies associated with known ENSO events

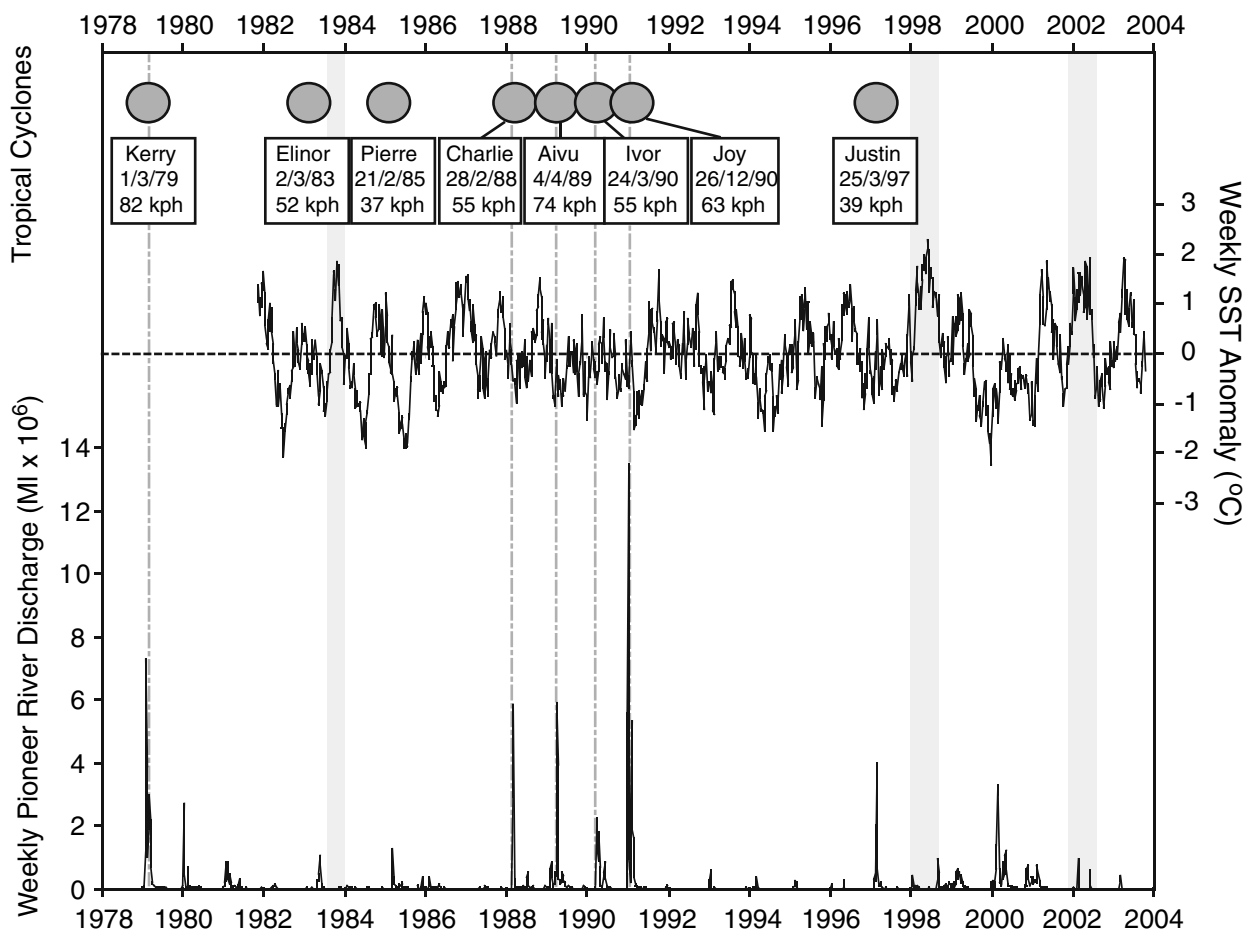


though transects were pooled to reef level due to the low overall numbers. Because high levels of turbidity in 2006 precluded photographic assessment of cover at Round Top Island, adjacent to the Pioneer River mouth, photoquadrats were used from surveys in September 2003. Preliminary analysis showed that the percent cover in 2003 for the most dominant classes (substratum, live hard coral, and macroalgal cover) were within the mean and standard deviation from line intercept data collected in March 2006, therefore conditions were unlikely to have substantially changed between monitoring periods. Quadrats of $0.5 \mathrm{~m} \times 0.5 \mathrm{~m}$ were placed along a $50 \mathrm{~m}$ measuring tape and photographed at $2 \mathrm{~m}$ intervals $(n=25$ photographs per transect). Photographs, taken with a Nikon e5000 camera, were analyzed with the CPCe random point count method (Kohler and Gill 2006) using 50 points per quadrat. Community structure was categorized by quantifying total cover of: live hard coral, soft coral, fleshy macroalgae, frondose calcareous algae (e.g., Halimeda sp.), bioeroding sponge (e.g., Cliona orientalis.), substratum (divided into dead intact coral, coral rubble, reef matrix, and sand), and other (dominated by the giant clam, Tridacna sp., anemones, large mollusks, hydroids and ascidians). To assess variability in coral assemblages at a coarse taxonomic level, coral cover was categorized into dominant families (Acroporidae, Pocilliporidae, Poritidae, Faviidae, and Others). Morphology of the dominant family, Acroporidae, was further separated into arborescent, caespitose, cuneiform, digitate, tabular, plating, and encrusting forms. Differences in live hard coral cover were assessed with a single factor ANOVA, followed by Tukey's HSD post-hoc test to identify significant pair-wise differences using
Statistica 8.0 software. Data were arcsine square-root transformed to meet the assumptions of normality and homogeneity of variance.

All community structure data were analyzed using the multivariate software PRIMER version 6.1.5. Community structure data (including coral families and growth form) were square-root transformed and similarities were calculated using the Bray-Curtis similarity measure (Bray and Curtis 1957). Multidimensional scaling (MDS) was used to ordinate transects, and hierarchical cluster analysis (groupaverage linkage) was performed to detect percent similarity levels. SIMilarities PERcentages (SIMPER) analysis was used to determine community structure categories that contributed to similarities among transects within each reef location and dissimilarities between locations (Clarke and Warwick 2001). Categories with less than $90 \%$ contribution to average dissimilarity between locations were excluded.

Coral core collection

In April 2004, December 2004, and March 2006, 10 cores were drilled from massive Porites colonies from Round Top, Keswick, and Scawfell Islands (Table 1). All cores were collected using SCUBA at bottom depths of 3-5 m below LAT using a pneumatic, hand-held underwater drill attached to a stainless steel coring barrel. Cores were slabbed ( $\sim 7 \mathrm{~mm}$ thick), cleaned ultrasonically in $18 \mathrm{M} \Omega$ water, and X-radiographed to visualize annual density bands to aid sampling for isotope analysis and chronology assignment.

Table 1 Specifications for Porites coral cores, including collection date, location, depth, total length of core, growth rate and type of analyses

\begin{tabular}{|c|c|c|c|c|c|c|c|}
\hline Core & Collection date & Lat $S$ & Lon E & $\begin{array}{l}\text { Collection } \\
\text { depth (m) }\end{array}$ & $\begin{array}{l}\text { Total length } \\
(\mathrm{cm})\end{array}$ & $\begin{array}{l}\text { Growth rate } \\
\left(\mathrm{mm} \mathrm{yr}^{-1}\right)\end{array}$ & Analyses \\
\hline \multicolumn{8}{|c|}{ Round Top Island } \\
\hline RTC & 4 April 2004 & 21.1755 & 149.2630 & 5 & 41 & $7.6 \pm 1.9$ & $\mathrm{~L}, \mathrm{~T}, \mathrm{~N}$ \\
\hline RTF & $\begin{array}{l}8 \text { December } \\
2004\end{array}$ & 21.1708 & 149.2644 & 4 & 61 & $8.3 \pm 1.8$ & $\mathrm{~T}, \mathrm{~N}$ \\
\hline RTH & 6 March 2006 & 21.1720 & 149.2639 & 4 & 186 & $8.7 \pm 2.4$ & $\mathrm{~L}, \mathrm{~T}, \mathrm{~N}$ \\
\hline RTI & 6 March 2006 & 21.1717 & 149.2634 & 4 & 86 & $8.7 \pm 1.7$ & $\mathrm{~L}$ \\
\hline \multicolumn{8}{|c|}{ Keswick Island } \\
\hline KIB & 1 April 2004 & 20.9177 & 149.4178 & 3 & 42 & $15.7 \pm 2.4$ & $\mathrm{~L}$ \\
\hline KIC & 1 April 2004 & 20.9177 & 149.4178 & 3 & 56 & $15.9 \pm 2.4$ & $\mathrm{~L}, \mathrm{~N}$ \\
\hline KIE & 13 March 2006 & 20.9319 & 14.4267 & N/A & 59 & $9.3 \pm 2.1$ & $\mathrm{~L}, \mathrm{~T}$ \\
\hline \multicolumn{8}{|c|}{ Scawfell Island } \\
\hline SCA & 1 April 2004 & 20.8552 & 149.6021 & 4 & 79 & $15.1 \pm 3.7$ & $\mathrm{~L}$ \\
\hline $\mathrm{SCB}$ & 1 April 2004 & 20.8552 & 149.6021 & 4 & 55 & $13.7 \pm 2.8$ & $\mathrm{~L}$ \\
\hline $\mathrm{SCC}$ & 1 April 2004 & 20.8552 & 149.6021 & 4 & 170 & $14.8 \pm 2.3$ & $\mathrm{~L}, \mathrm{~T}, \mathrm{~N}$ \\
\hline
\end{tabular}

L, luminometer measurements of luminescence intensity; T, LA-ICP-MS measurements of trace elements; N, bulk annual measurements of skeletal insoluble organic $\delta^{15} \mathrm{~N}$ 
Coral luminescence analysis

Coral luminescence (excitation $\lambda(\mathrm{nm}) / \mathrm{emission} \quad \lambda$ $(\mathrm{nm})=390 / 490)$ was measured at $0.25 \mathrm{~mm}$ increments along the length of whole skeletal slabs using a fully automated, custom assembled optical luminometry device at the Australian Institute of Marine Science following the protocol of Barnes et al. (2003). To correct for drift within and between sample runs, luminescence and reflectance were measured from background (black "delrin" plastic disk) and calcium carbonate (Tridacna maxima shell) standards at the start and end of each run. Relative luminescence for all measurements along each coral slice was then calculated by the following equation (Barnes et al. 2003):

\section{Relative luminescence}

$$
=\frac{\left(\text { lumin }_{\text {coral }}-\text { lumin }_{\text {bkgd }}\right)}{\left(\text { lumin }_{\text {std }}-\text { lumin }_{\text {bkgd }}\right)} / \frac{\left(\text { reflect }_{\text {coral }}-\text { reflect }_{\text {bkgd }}\right)}{\left(\text { reflect }_{\text {std }}-\text { reflect }_{\text {bkgd }}\right)}
$$

Measurements of skeletal density $\left(\mathrm{g} \mathrm{cm}^{-3}\right)$ were made at the same time as luminescence measurements along the same track of each coral slice. Density was measured by the attenuation of a beam of gamma photons, centered $37.34 \mathrm{~mm}$ ahead of the center of the light beam used to measure luminescence. Chronologies were constructed by assuming minimum density deposition occurred during minimum winter SSTs (first week of August, based on IGOSS regional $1^{\circ}$ gridded weekly SST records, November 1981-December 2004, http://www.iridl.ldeo.columbia.edu/ SOURCES/.IGOSS/.nmc/). Because the strength of relationships with climatic variables varies among different corals and, in some cases, over time within a single record, a master record was created from each location using the average of three replicate cores with overlapping data between February 1978 and August 2002 (Lough 2004). Data were excluded from the top years of the cores ( $>2003$ ) due to the patchy, elevated luminescence associated with oxidized organic material from the residual tissue of coral polyps, algal symbionts, and endolithic algae (Barnes et al. 2003).

To assess the influence of Pioneer River discharge on coral luminescence, annual peak luminescence was correlated with total annual discharge (October-September). Nonparametric Spearman Rank Correlation tests were used because the peak luminescence values from the master coral records were non-normally distributed. To assess whether the influence of river floods was visible over background variability (i.e., seasonal luminescent bands; Barnes et al. 2003) at each location, two-way ANOVA tests were used to assess differences between annual maximum - mean luminescence values for 4 of the wettest years (annual Pioneer discharge $>1,000,000 \mathrm{Ml}$ : 1979, 1989, 1990, 1991 or
1988) versus the four driest years (annual Pioneer discharge <80,000 Ml: 1987, 1992, 1995, 1996) between 1978 and 2002 at each location. Data conformed to assumptions of normality (Shapiro-Wilk's W test) and homogeneity of variance (Levene's tests). The effect size of each factor (core, discharge level, core*discharge level) is reported with the eta squared $\left(\eta^{2}\right)$ statistic (Cohen 1973). All analyses were performed with Statistica 8.0 software. 1991 was excluded from the Round Top analysis because the RTI colony experienced partial mortality from the event: the residual organic matter in the flood band resulted in an outlier value of highly elevated luminescence. 1988 was excluded from the Keswick and Scawfell analyses due to data gaps in KIE and SCB where the slabs were fractured.

Coral trace element analysis

Trace element concentrations of ${ }^{43} \mathrm{Ca},{ }^{84} \mathrm{Sr}$, and ${ }^{138} \mathrm{Ba}$ in five of the coral cores (RTC, RTF, RTH, KIE, SCC) were analyzed by laser ablation inductively coupled mass spectrometry (LA-ICPMS) with an ArF excimer laser (193 nm wavelength) attached to either a modified VG Elemental $\mathrm{PQ}^{+}$or Varian 820 ICP-MS. Specifications for the laser system, data collection, and protocol for instrumental drift correction were identical to that described by Sinclair et al. (1998), except that the laser spot size was changed to $40 \mu \mathrm{m} \times 400 \mu \mathrm{m}$, yielding a sampling resolution of $20 \mathrm{~nm}$ operated at $5 \mathrm{~Hz}$. All isotopic concentrations were normalized to ${ }^{43} \mathrm{Ca}(0.13 \% \mathrm{Ca})$ to account for variations due to changes in coral surface architecture and density (Fallon et al. 1999). Data were smoothed using a 10-point running median to remove outliers, followed by a 10-point mean to reduce data volume. Time series of the corals were calibrated by matching $\mathrm{Sr} / \mathrm{Ca}$ maximum and minimum values to IGOSS $1^{\circ}$ gridded weekly SST records (Beck et al. 1992). For data before 1981, the average week of SST summer maxima and winter minima was used. To assess the influence of Pioneer River discharge on coral $\mathrm{Ba} / \mathrm{Ca}$ values across the nearshore spatial gradient, nonparametric Spearman Rank correlations were used to evaluate relationships between annual peak $\mathrm{Ba} / \mathrm{Ca}(\mu \mathrm{mol} / \mathrm{mol})$ with total annual discharge (October-September), while parametric Pearson product-moment correlations were used to compare weekly $\mathrm{Ba} / \mathrm{Ca}\left(\mu \mathrm{mol} \mathrm{mol}{ }^{-1}\right)$ with weekly logtransformed discharge. Ba/Ca records (1968-2003) from Round Top Island cores (RTC, RTF, RTH) were averaged prior to correlation analysis.

Coral skeletal $\delta^{15} \mathrm{~N}$ analysis

The $\delta^{15} \mathrm{~N}$ composition of acid-insoluble coral skeletal nitrogen was analyzed from cores RTC, RTF, RTH, KIC, and SCC using protocols established by Marion (2007). The 
insoluble fraction represents $51 \%$ of total skeletal nitrogen and compositionally is closely related to sources and transformations of nitrogen in the water column (Marion 2007). Prior to sample preparation, an ultra-fine ( $<1 \mathrm{~mm}$ thick) layer was cut from each slab to remove superficial contamination. Annual density bands were mapped from $\mathrm{X}$-radiographs onto core slices to aid in drilling annual coral carbonate samples (1.5-2.8 g). Samples were ground to a powder, decalcified in $\mathrm{H}_{3} \mathrm{PO}_{4}$, filtered (Whatman $\mathrm{GF} / \mathrm{F}$, $0.7 \mu \mathrm{m}$ pore size) to retain the acid-insoluble organic fraction, dried for $24 \mathrm{~h}$ at $60^{\circ} \mathrm{C}$, and loaded in $9 \times 10 \mathrm{~mm}$ tin capsules into a 31-run multi-sampler carousel. Samples were analyzed using a Carlo Erba NA1500 elemental analyzer (EA) coupled to a Finnigan MAT Delta + mass spectrometer via a ConFlo II open split interface (Stanford University Stable Isotope Laboratory). Six isotopic (IAEA-N1, USGS24) and seven elemental (acetanilide) standards were analyzed with each set of $40 \mathrm{C} / \mathrm{N}$ samples, yielding instrument standard deviations of $0.07 \%\left(\delta^{15} \mathrm{~N}\right)$.

A 3-core composite time series (1970-2004) was developed for Round Top Island by averaging the annual $\delta^{15} \mathrm{~N}$ values for RTC, RTF, and RTH. Nonparametric Spearman Rank correlations were used to assess relationships between annual $\delta^{15} \mathrm{~N}$ and total annual river discharge (OctoberSeptember). The frequency with which coral $\delta^{15} \mathrm{~N}$ exceeded $9 \%$ is also reported, indicating significant enrichment of particulate organic matter (POM) discharged by the Pioneer River resulting from elevated anthropogenic inputs of biologically available (fertilizer-derived) dissolved inorganic nitrogen and subsequent microbial transformations (Marion 2007). The $9 \%$ value represents the mean of POM filtered from water samples collected from stagnant pools adjacent to weirs on the lower Pioneer River, which were enriched by approximately 6\% over upper Pioneer River POM measurements. Coupled nutrient analysis of water samples from the lower Pioneer pools showed elevated particulate nitrogen (PN) and dissolved organic nitrogen (DON) and low ammonium and nitrate concentrations (Marion 2007). The elevated particulate nitrogen and DON concentrations likely reflect high microbial biomass and remineralization, while the low nitrate and ammonium concentrations, both of which are reactants in denitrification (Middleburg and Nieuwenhuize 2001), suggest rapid attenuation rates produced the heavy, signature $\delta^{15} \mathrm{~N}$ values of the lower Pioneer waters that are flushed into the nearshore during flood events.

\section{Results}

Coral community assemblages

High, significant cross-shelf variability in live hard coral cover was observed $\left(F_{6,37}=11.305, P<0.001\right.$; Table 2$)$.
Values ranged from $3.3 \pm 3.2 \%$ (mean $\pm \mathrm{SE}$ ) at Keswick Island (KI, $32 \mathrm{~km}$ from Pioneer River mouth) to peak cover of $28.9 \pm 2.1 \%$ at Big Kindemar $(\mathrm{BK}, \sim 130 \mathrm{~km}$ from the Pioneer mouth and $\sim 70 \mathrm{~km}$ perpendicular distance from the outer shelf of the Pompey Complex). The reefs closest to the mainland (Round Top [RT], KI, and St. Bees [SB] were all characterized by low live coral cover: percent cover at the innermost location (RT: $7.3 \pm 2.4 \%$ ) was slightly higher than at $\mathrm{KI}$, though differences among all three locations were not significant.

Reef structure and composition, however, varied substantially between the most inshore locations. Rubble, reef matrix, and sand were the dominant benthic cover at RT (90.5 $\pm 3.1 \%$; Table 2), with low densities of massive Porites sp. adjacent to the transects, low abundances of juvenile acroporids and sparse, small colonies of mainly encrusting Montipora and foliaceous Turbinaria settled on rock or rubble and covered in turf algae and thick sediment. Only small amounts of fleshy macroalgae were observed at this location $(1.7 \pm 0.5 \%)$. By contrast, tall stands of fleshy brown algae, particularly Sargassum sp. and Padina sp., dominated benthic cover at $\mathrm{KI}$ and SB $(80.1 \pm 7.2 \%$ and $62.7 \pm 7.1 \%$, respectively), overgrowing dead reef framework and rubble substrate. Very few fleshy macroalgae were observed at any other reef. At SC (the next island offshore), the shallow, often turbid reefs were dominated by soft corals $(31.3 \pm 4.6 \%)$. The middle-shelf reef at Derwent (DR) had a high cover of crustose coralline algae binding a well-developed reef flat that dropped steeply to rubble and pavement at $\sim 10 \mathrm{~m}$. The eastern, more exposed side of the reef flat had high occurrences of boring sponge (Cliona orientalis), which was not observed in high abundance at any other reef. The two outer reefs (BK and LK), both broad reef platforms about 9 to $13.5 \mathrm{~km}$ across, also had well-consolidated reef matrix, low fleshy macroalgae, and higher soft coral cover (BK: $8.8 \pm 4.0 \%$; LK: $8.8 \pm 3.0 \%$ ), such that the totals of live hard coral and soft coral were very similar to that observed at DR.

Cluster analysis identified four main groups from the community structure data from 20 transects, which are illustrated in an MDS plot (Fig. 3). Group 4 (outer middle-shelf transects: DR, LK, BK) and Group 3 (SC transects) clustered at $58.8 \%$ similarity. Together, Groups 3 and 4 were only $44.1 \%$ similar to Group 1 transects (RT) and 36.9\% similar to Group 2 transects (KI and SB). The SIMPER analysis identified the benthic categories that contributed most to the similarities within groups and the differences between groups (Fig. 4). KI and SB were categorically different from all other reefs due to the high cover of fleshy macroalgae (Fig. 4b), though it was recognized that the thick algal canopy may have obscured the presence of an epilithic algal understory, juvenile corals, and consolidated reef matrix. The dissimilarity 
Table 2 Mean percent cover \pm SE for benthic habitat categories scored from photoquadrats and used as input for multivariate analyses

\begin{tabular}{|c|c|c|c|c|c|c|c|}
\hline & Round Top & Keswick & St. Bees & Scawfell & Derwent & Little Kindemar & Big Kindemar \\
\hline \multicolumn{8}{|l|}{ Coral composition } \\
\hline Acroporidae & $3.0 \pm 0.8$ & $2.8 \pm 0.4$ & $9.2 \pm 0.7$ & $14.4 \pm 1.2$ & $16.5 \pm 0.9$ & $12.8 \pm 0.7$ & $19.1 \pm 1.8$ \\
\hline Arborescent & $0.9 \pm 0.4$ & $2.1 \pm 2.0$ & $3.2 \pm 1.4$ & $4.3 \pm 2.2$ & $0.4 \pm 0.3$ & $1.7 \pm 0.9$ & $2.4 \pm 2.0$ \\
\hline Caespitose & - & - & $1.4 \pm 0.7$ & $2.5 \pm 1.7$ & $0.4 \pm 0.2$ & $3.8 \pm 0.7$ & $4.5 \pm 2.1$ \\
\hline Cueniform & - & - & $0.5 \pm 0.3$ & $0.7 \pm 0.4$ & $2.1 \pm 0.1$ & $1.4 \pm 0.8$ & $4.2 \pm 3.8$ \\
\hline Digitate & $0.2 \pm 0.2$ & - & $1.0 \pm 0.8$ & $3.4 \pm 2.1$ & $11.0 \pm 5.1$ & $1.3 \pm 0.4$ & $3.2 \pm 2.5$ \\
\hline Tabular & - & - & $0.5 \pm 0.3$ & - & $1.2 \pm 0.7$ & $0.1 \pm 0.1$ & $0.5 \pm 0.5$ \\
\hline Plating & - & $0.6 \pm 0.6$ & $2.2 \pm 1.8$ & $1.5 \pm 1.4$ & $0.1 \pm 0.1$ & $1.1 \pm 0.6$ & $1.8 \pm 1.7$ \\
\hline Encrusting & $1.9 \pm 0.5$ & $0.1 \pm 0.1$ & $0.36 \pm 0.2$ & $2.1 \pm 2.0$ & $0.3 \pm 0.2$ & $1.5 \pm 0.9$ & $0.9 \pm 0.4$ \\
\hline Other & - & - & - & - & $1.2 \pm 0.7$ & $0.1 \pm 0.1$ & $0.5 \pm 0.5$ \\
\hline Pocilloporiidae & $0.3 \pm 0.2$ & - & - & $0.7 \pm 0.2$ & $0.8 \pm 0.4$ & $1.9 \pm 0.4$ & $2.8 \pm 1.0$ \\
\hline Faviidae & $1.2 \pm 0.9$ & - & - & $0.3 \pm 0.3$ & $5.2 \pm 1.0$ & $0.9 \pm 0.2$ & $0.7 \pm 0.6$ \\
\hline Poritidae & $0.3 \pm 0.3$ & - & $0.2 \pm 0.2$ & $0.7 \pm 0.5$ & $0.1 \pm 0.1$ & $1.3 \pm 0.8$ & $0.8 \pm 0.7$ \\
\hline Other coral & $2.5 \pm 0.9$ & $0.4 \pm 0.4$ & $0.7 \pm 0.2$ & $1.6 \pm 0.7$ & $0.5 \pm 0.2$ & $7.6 \pm 2.4$ & $5.7 \pm 0.9$ \\
\hline \multicolumn{8}{|l|}{ Community structure } \\
\hline Total coral & $7.3 \pm 2.4$ & $3.3 \pm 3.2$ & $10.1 \pm 2.7$ & $17.7 \pm 3.0$ & $23.3 \pm 6.6$ & $24.4 \pm 2.2$ & $28.9 \pm 2.1$ \\
\hline Halimeda & - & $0.1 \pm 0.1$ & $0.1 \pm 0.1$ & $0.1 \pm 0.0$ & - & $3.4 \pm 2.6$ & $8.7 \pm 8.4$ \\
\hline Macroalgae & $1.7 \pm 0.5$ & $80.1 \pm 7.2$ & $62.7 \pm 7.1$ & $0.3 \pm 0.2$ & - & $0.2 \pm 0.2$ & - \\
\hline Soft coral & $0.5 \pm 0.2$ & $0.1 \pm 0.1$ & $0.1 \pm 0.0$ & $31.3 \pm 4.6$ & $10.6 \pm 3.8$ & $8.8 \pm 3.0$ & $8.8 \pm 4.0$ \\
\hline Bioeroding sponge & - & $1.0 \pm 0.1$ & $1.0 \pm 0.5$ & $0.2 \pm 0.2$ & $9.7 \pm 6.2$ & $0.6 \pm 0.1$ & - \\
\hline Other & - & - & $0.1 \pm 0.0$ & $0.1 \pm 0.0$ & $0.4 \pm 0.1$ & $0.9 \pm 0.1$ & $0.5 \pm 0.5$ \\
\hline Substrate & $90.5 \pm 3.1$ & $15.4 \pm 3.7$ & $26.1 \pm 7.1$ & $50.4 \pm 3.9$ & $56.1 \pm 3.6$ & $61.8 \pm 6.0$ & $53.1 \pm 14.0$ \\
\hline Dead coral intact & $0.3 \pm 0.1$ & $2.1 \pm 0.5$ & - & $14.8 \pm 3.5$ & $1.7 \pm 0.2$ & $4.5 \pm 0.8$ & $1.6 \pm 0.2$ \\
\hline Coral rubble & $41.4 \pm 10.1$ & $1.1 \pm 1.1$ & $3.8 \pm 3.8$ & $0.9 \pm 0.9$ & $0.3 \pm 0.3$ & $3.7 \pm 1.9$ & $2.2 \pm 1.9$ \\
\hline Reef matrix & $15.7 \pm 2.4$ & $8.8 \pm 2.2$ & $13.8 \pm 1.0$ & $34.3 \pm 3.2$ & $52.9 \pm 3.6$ & $47.5 \pm 6.1$ & $46.5 \pm 11.9$ \\
\hline Sand & $32.9 \pm 6.4$ & $3.4 \pm 2.7$ & $8.5 \pm 4.1$ & $0.4 \pm 0.4$ & $1.2 \pm 0.3$ & $6.2 \pm 2.7$ & $2.7 \pm 0.4$ \\
\hline
\end{tabular}

Fig. 3 Multidimensional scaling (MDS) plot of coral community data from Round Top Island (RT), Keswick Island (KI), St. Bees Island (SB), Scawfell Island (SC), Derwent Island (DR), Little Kindemar Reef (LK) and Big Kindemar Reef (BK). Circles around clusters of transect data points represent minimum $\%$ similarity between groups

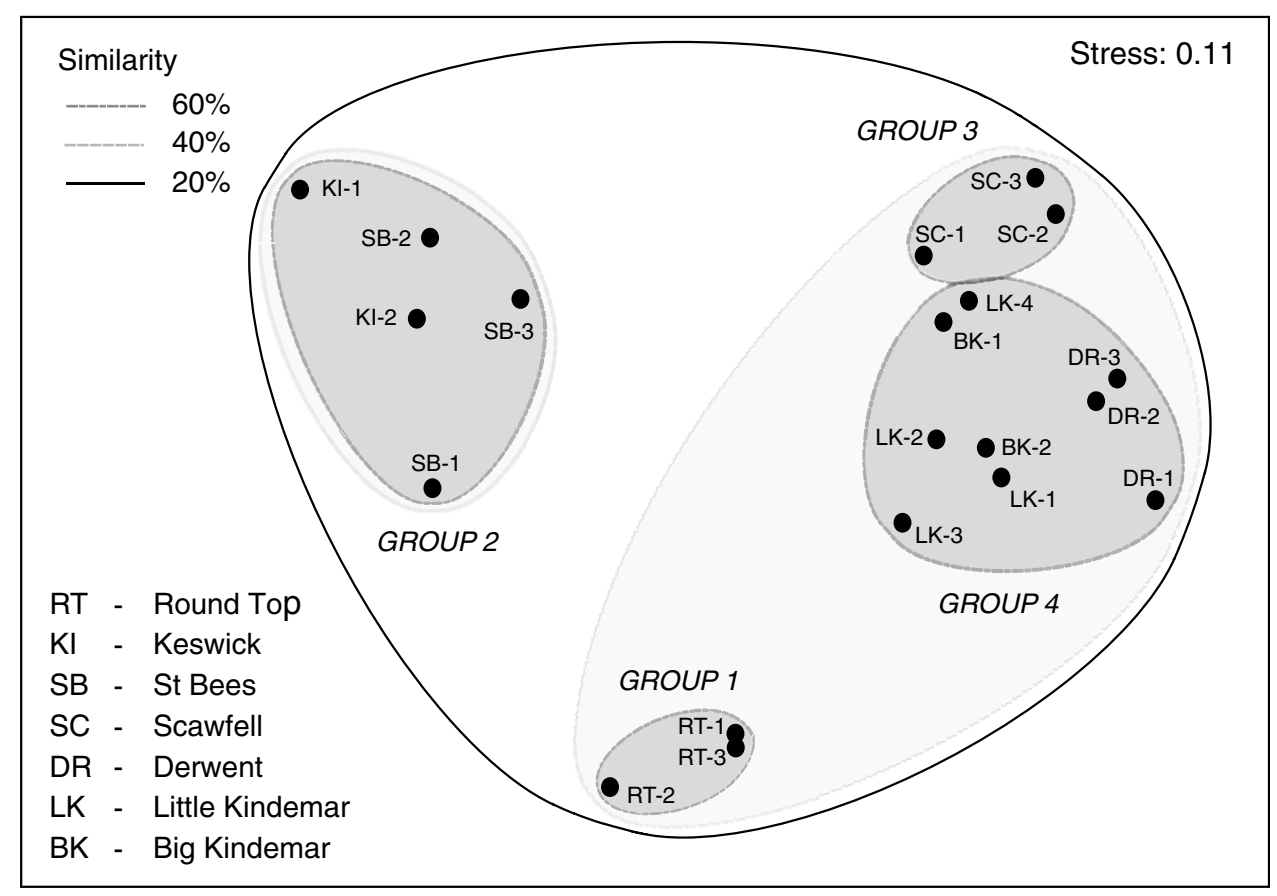




\begin{tabular}{|c|c|c|c|c|c|c|}
\hline Round Top & Keswick & St. Bees & Scawfell & Derwent & $\begin{array}{c}\text { Little } \\
\text { Kindemar }\end{array}$ & $\begin{array}{c}\text { Big } \\
\text { Kindemar }\end{array}$ \\
\hline $87.1 \%$ & $82.9 \%$ & $85.0 \%$ & $89.3 \%$ & $84.4 \%$ & $82.0 \%$ & $73.3 \%$ \\
\hline $\begin{array}{l}\text { Reef Matrix } \\
\text { Acroporidae } \\
\text { Other Coral }\end{array}$ & $\begin{array}{l}\text { Macroalgae } \\
\text { Reef Matrix } \\
\text { Acroporidae }\end{array}$ & $\begin{array}{l}\text { Macroalgae } \\
\text { Reef Matrix }\end{array}$ & $\begin{array}{l}\text { Reef Matrix } \\
\text { Soft Coral } \\
\text { Acroporidae }\end{array}$ & $\begin{array}{l}\text { Reef Matrix } \\
\text { Soft Coral } \\
\text { Acroporidae } \\
\text { Faviidae }\end{array}$ & $\begin{array}{l}\text { Reef Matrix } \\
\text { Soft Coral } \\
\text { Acroporidae } \\
\text { Other Coral } \\
\text { Faviidae }\end{array}$ & $\begin{array}{l}\text { Reef Matrix } \\
\text { Soft Coral } \\
\text { Acroporidae } \\
\text { Other Coral }\end{array}$ \\
\hline
\end{tabular}

\section{b Round Top}

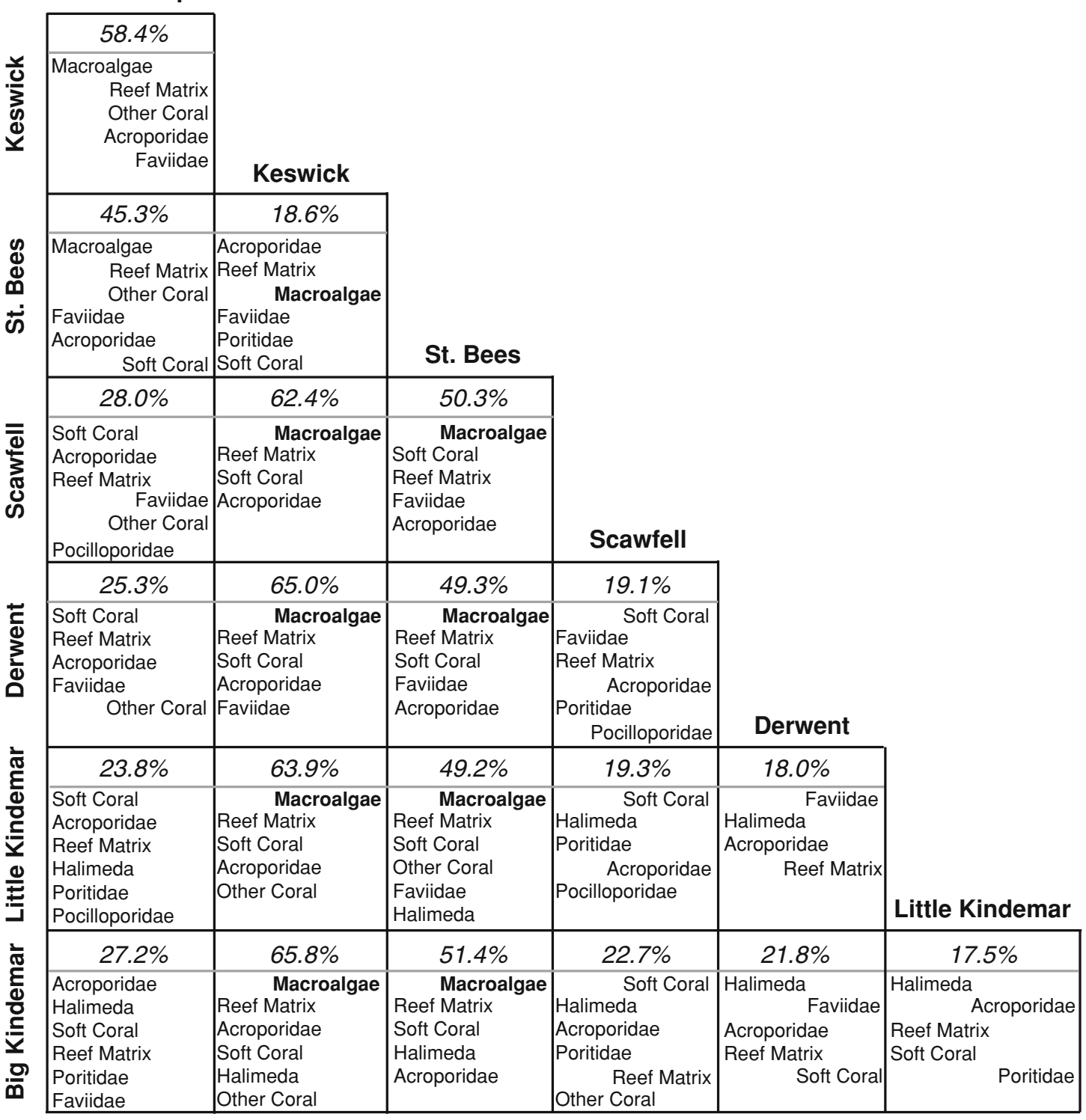

Fig. 4 Results of SIMPER analysis showing benthic cover classes that contributed most strongly to (a) similarity between transects at each survey location, and (b) differences between locations. Benthic cover classes are listed in order of their contribution to similarities

between SC and the Group 4 locations (19.1-22.7\%) was within range of the dissimilarity among the Group 4 locations (17.5-21.8\%) and was most distinguished by the and dissimilarities. In the dissimilarity matrix, categories to the left of each cell were more abundant at the location labeled by row, while categories to the right were more abundant at the location labeled by column

high cover of soft corals (Fig. 4b). While acroporid corals were the dominant family at all locations, the Group 4 locations had higher proportions of other representative 
families and the highest cover of carbonate reef matrix (Table 2).

\section{Coral luminescence}

Mean relative coral luminescence intensity from the master coral records at each location decreased with distance from the Pioneer River mouth (mean $\pm \mathrm{SD}$ for RT:
$0.746 \pm 0.091 ; \mathrm{KI}: 0.501 \pm 0.056 ;$ SC: $0.379 \pm 0.035$; Fig. 5). The RT cores showed distinct annual luminescent lines even in low flow years which resulted in the lack of significant correlation $(P=0.099)$ between annual peak luminescence and Pioneer River discharge (Table 3a). The difference between maximum - mean luminescence in wet versus dry years was significant $\left(F_{1,18}=12.851\right.$, $P=0.0021)$ and explained $\sim 41 \%$ of the variance among
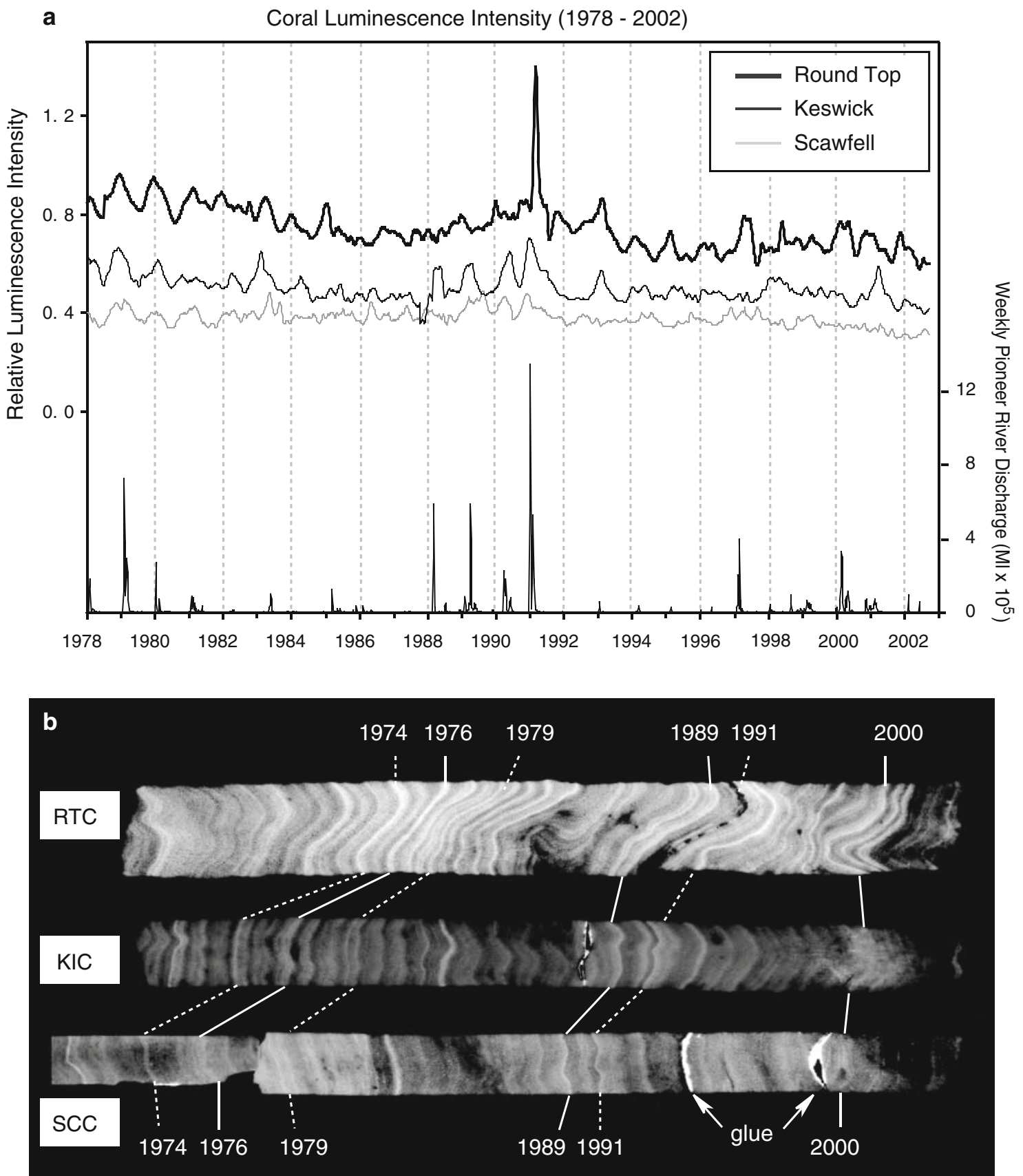

Fig. 5 (a) Relative luminescence intensity for Round Top (black bold), Keswick (medium grey) and Scawfell (light grey) corals between 1978 and 2002. Each line represents a 3-core average. Weekly Pioneer discharge $\left(\mathrm{Ml} \times 10^{5}\right)$ is shown below. (b)
Representative core slabs from Round Top (RTC), Keswick (KIC) and Scawfell (SCC) photographed under UV light. White lines between cores connect luminescent lines from major flood years 
Table 3 Spearman Rank correlations of annual Pioneer discharge versus: (a) maximum relative luminescence intensity (1978-2002); (b) peak $\mathrm{Ba} / \mathrm{Ca}$ concentrations (1968-2002); and (c) coral skeletal $\delta^{15} \mathrm{~N}(1970-2002)$

\begin{tabular}{|c|c|c|c|c|}
\hline Site & $n$ & Spearman $R$ & $t$ & $P$ \\
\hline \multicolumn{5}{|c|}{ (a) Maximum luminescence vs. Total discharge (1978-2002) } \\
\hline Round Top Island & 25 & 0.338 & 1.721 & 0.099 \\
\hline Keswick Island & 25 & 0.511 & 2.849 & 0.009 \\
\hline Scawfell Island & 25 & 0.406 & 2.132 & 0.044 \\
\hline \multicolumn{5}{|c|}{ (b) Maximum Ba/Ca vs. Total discharge (1968-2002) } \\
\hline Round Top Island & 35 & 0.427 & 2.716 & $\mathbf{0 . 0 1 0}$ \\
\hline Keswick Island & 35 & 0.228 & 1.344 & 0.188 \\
\hline Scawfell Island & 35 & -0.052 & -0.301 & 0.765 \\
\hline \multicolumn{5}{|c|}{ (c) Coral skeletal $\delta^{15} \mathrm{~N}$ vs. Total discharge (1970-2002) } \\
\hline Round Top Island & 33 & 0.611 & 4.293 & 0.000 \\
\hline Keswick Island & 33 & 0.382 & 2.304 & $\mathbf{0 . 0 2 8}$ \\
\hline Scawfell Island & 33 & -0.059 & -0.330 & 0.744 \\
\hline
\end{tabular}

Significant $P$ values are in bold

Table 4 Two-way ANOVA of differences between maximum minus mean luminescence values in wet years (annual Pioneer discharge $>1,000,000 \mathrm{Ml}$ ) versus dry years (annual Pioneer discharge $<80,000 \mathrm{Ml}$ ) for: (a) Round Top Island; (b) Keswick Island; (c) Scawfell Island

\begin{tabular}{lrlrll}
\hline Source of variation & df & \multicolumn{1}{l}{ MS } & \multicolumn{1}{l}{$F$} & $P$ & $\eta^{2}$ \\
\hline (a) Round Top Island & & & & & \\
Core & 2 & 0.0002 & 0.200 & 0.8203 & 0.013 \\
$\quad$ Discharge level & 1 & 0.0137 & 12.851 & $\mathbf{0 . 0 0 2 1}$ & 0.406 \\
Core*Discharge level & 2 & 0.0002 & 0.214 & 0.8092 & 0.014 \\
$\quad$ Error & 18 & 0.0011 & & & \\
(b) Keswick Island & & & & & \\
Core & 2 & 0.0006 & 1.929 & 0.1741 & 0.038 \\
Discharge level & 1 & 0.0239 & 76.689 & $\mathbf{0 . 0 0 0 0}$ & 0.758 \\
Core*Discharge level & 2 & 0.0004 & 1.292 & 0.2989 & 0.026 \\
$\quad$ Error & 18 & 0.0003 & & & \\
(c) Scawfell Island & & & & & \\
Core & 2 & 0.004 & 1.297 & 0.2978 & 0.066 \\
Discharge level & 1 & 0.0056 & 18.374 & $\mathbf{0 . 0 0 0 4}$ & 0.469 \\
Core*Discharge level & 2 & 0.0000 & 0.101 & 0.9041 & 0.005 \\
$\quad$ Error & 18 & 0.0003 & & & \\
\hline
\end{tabular}

RT cores (Table 4a). At KI, peak annual luminescence in the master coral record was significantly correlated with Pioneer discharge $(P=0.009)$, and wet versus dry years explained $\sim 76 \%$ of the total variance $\left(F_{1,18}=76.689\right.$, $P<0.001$ ) in maximum - mean luminescence (Table $4 \mathrm{~b}$ ). The same pattern was observed, though weaker, at SC where peak annual luminescence in the master coral record was significantly correlated with Pioneer discharge $(P=0.044)$, and wet versus dry years explained $\sim 47 \%$ of the variability $\left(F_{1,18}=18.374, \quad P=0.004\right) \quad$ in maximum - mean luminescence (Table 4c). In the RT master core record, the difference between maximum mean luminescence exceeded 0.1 in 9 years of the 25 year record, including major flood years $(1979,1990,1991)$, El Niño years $(1982,1983,1993)$, and other years $(1978,1980$, 1981). The difference was greater than 0.1 in 6 of the above years $(1978,1979,1980,1983,1990,1991$, and 1993) in the KI master core, but only in 3 years $(1983,1989$, and 1991) in the $\mathrm{SC}$ master core.

\section{Coral $\mathrm{Ba} / \mathrm{Ca}$}

Mean coral $\mathrm{Ba} / \mathrm{Ca}$ concentration decreased with distance from the Pioneer River mouth (mean $\pm \mathrm{SD}$ for RT master: $4.98 \pm 0.63 \mu \mathrm{mol} \mathrm{mol}^{-1}$; KIE: $4.20 \pm 0.52 \mu \mathrm{mol} \mathrm{mol}^{-1}$; SCC: $3.55 \pm 0.98 \mu \mathrm{mol} \mathrm{mol}^{-1}$ ). The master record from RT exhibited smooth annual peaks whose maximum values were significantly correlated with annual Pioneer River discharge $(P=0.010$; Fig. 6 , Table $3 b)$. Baseline winter $\mathrm{Ba} / \mathrm{Ca}$ values remained elevated during wetter periods (1974-1980, 1988-1991 and, to a lesser extent, 19982002). Weekly $\mathrm{RT} \mathrm{Ba} / \mathrm{Ca}$ values were also significantly related to weekly discharge $(\mathrm{df}=1839, t=14.312$, $P<0.001$ ), but only accounted for a small proportion $\left(r^{2}=0.10\right)$ of the overall variance. The KI coral also had clear annual $\mathrm{Ba} / \mathrm{Ca}$ peaks but the maximum values were not correlated with annual discharge $(P=0.188$, Table $3 b)$. Although the KIE core had moderately elevated

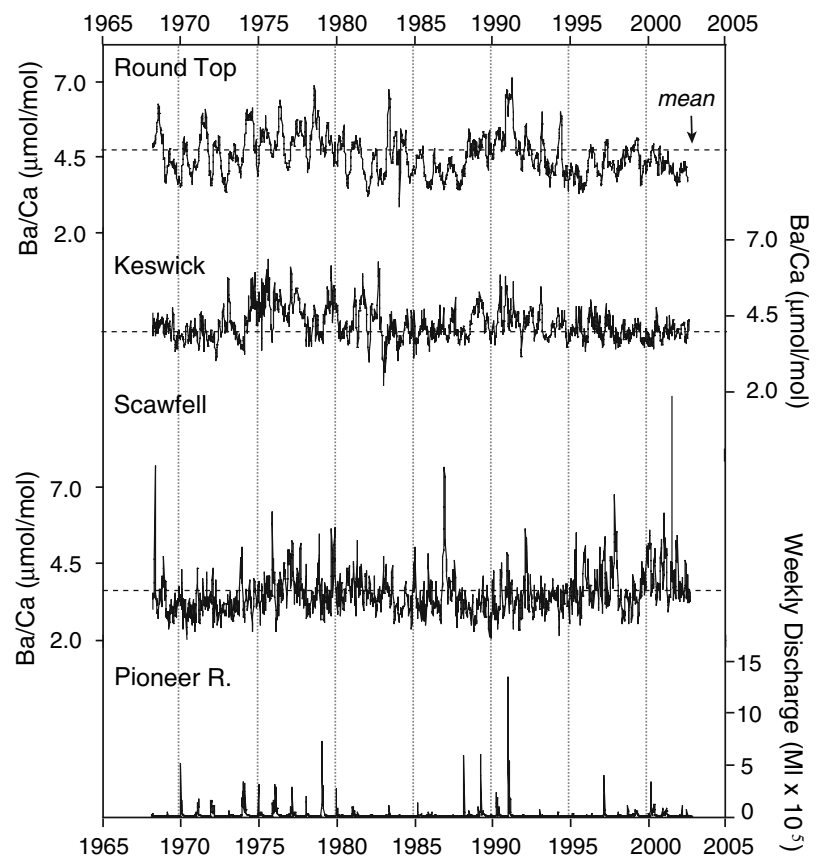

Fig. 6 Coral records of weekly $\mathrm{Ba} / \mathrm{Ca}$ from Round Top, Keswick and Scawfell islands. The Round Top values for $\mathrm{Ba} / \mathrm{Ca}$ are an average of three records. Horizontal dashed lines are mean values for each location. Weekly Pioneer discharge is plotted below 
winter minima and summer peaks between 1974 and 1980, the record between 1988 and 1991 was highly variable (Fig. 6). The significant correlation between weekly $\mathrm{Ba} / \mathrm{Ca}$ and weekly discharge $(\mathrm{df}=1839, t=2.30, P=0.022)$ was likely an artifact of high sample size given the low correlation coefficient $\left(r^{2}=0.003\right)$. The $\mathrm{Ba} / \mathrm{Ca}$ record from SC was highly variable and had no significant relationship with Pioneer River discharge.

\section{Coral skeletal $\delta^{15} \mathrm{~N}$}

Mean coral skeletal $\delta^{15} \mathrm{~N}$ declined by $\sim 4.5 \%$ with increasing distance offshore (mean \pm SD for RT master: $8.15 \pm 1.29 \%$; KIC: $5.65 \pm 2.67 \%$; SCC: $3.54 \pm 2.63 \%$ ). Annual coral $\delta^{15} \mathrm{~N}$ was positively correlated with annual Pioneer discharge at both RT $(P<0.001)$ and KI $(P=0.028)$, but not at SC $(P=0.744$; Table $3 \mathrm{c})$. The $\delta^{15} \mathrm{~N}$ values in the RT master record ranged from 6.00 to $11.13 \%$ and exceeded the threshold 9\%o (Pioneer catchment "source"; Marion 2007) 11 times in the 33-year record, predominantly during large flood years (1970, $1974,1976,1977,1979,1989,1991,2000)$ or in years following extreme events or multiple wet years (1975, 1978, 1992; Fig. 7). At KI, $\delta^{15} \mathrm{~N}$ values ranged from 2.50 to $13.62 \%$, exceeding $9 \%$ only in 1974 and 1991, coincident with two of the three largest flood years in the record. Isotopic data from SC were generally more

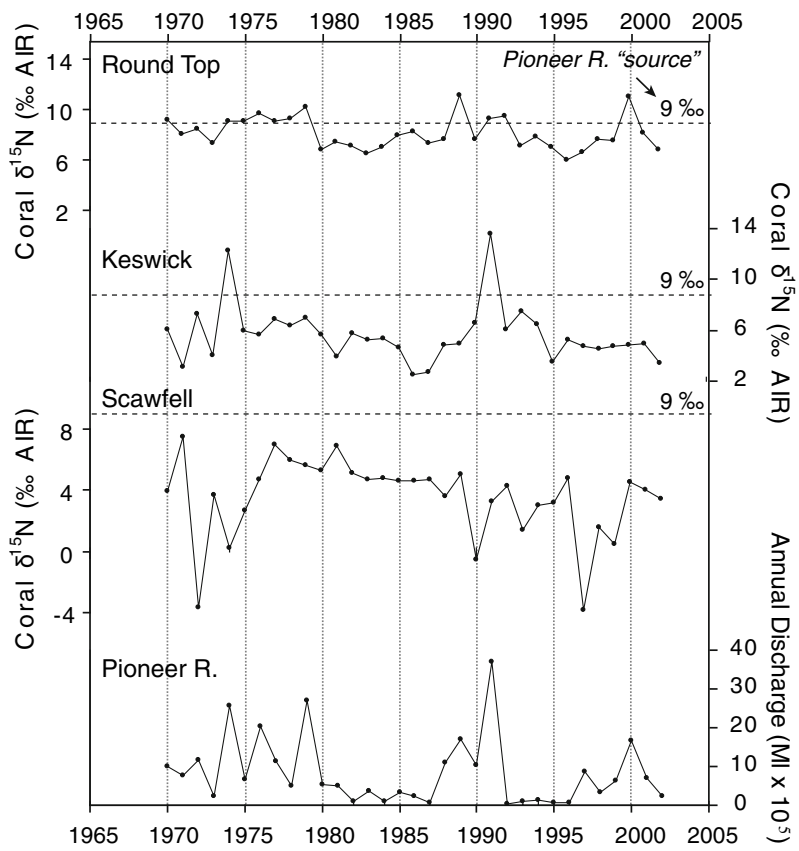

Fig. 7 Coral records of annual $\delta^{15} \mathrm{~N}$ from Round Top, Keswick and Scawfell islands. The Round Top values for $\delta^{15} \mathrm{~N}$ are an average of three records. Horizontal dashed lines indicate source value from lower Pioneer River reservoirs $(9 \%$ ) that is discharged into nearshore waters during flood events. Annual Pioneer discharge is plotted below depleted and consistently below the $9 \%$ threshold, ranging from -3.82 to $7.50 \%$.

\section{Discussion}

The position of a reef across the continental shelf and its relative proximity to highly modified terrestrial catchments will affect its exposure to terrestrial discharge and, therefore, the frequency of major disturbances. Given the perceived role of disturbance history in shaping presentday coral communities (Hughes 1989), it is highly likely that disturbance events and/or chronic stressors may have influenced the community structure of reefs in the Mackay region. Here, the disturbance regime for this region is reconstructed, using biogeochemical coral proxies of the frequency and intensity with which the nearshore locations are exposed to acute flood events and chronic turbidity plus nutrient enrichment. The magnitude and frequency of terrestrial exposure are discussed in relation to coral assemblage data to assess likelihood of direct and indirect effects on coral community composition (Fabricius 2005).

\section{Group 1: Chronic, high-magnitude exposure}

Nearshore reefs located adjacent to river drainages have particularly high rates of disturbance. In addition to the main categories of disturbance that affect offshore reefs ecosystems worldwide (e.g., bleaching, tropical cyclone damage, predation, overfishing), nearshore reefs are also subject to both acute and chronic disturbance from terrestrial discharge that can affect reef development and persistence. Due to an evident lack of accreted carbonate framework, the coral assemblages at Round Top resemble an 'incipient reef' (sensu Hopley et al. 1989), which has not formed a true reef flat and consists mainly of thin carbonate veneers and isolated coral colonies at under $10 \%$ cover. Given the historically recent and severe land modification of the Pioneer catchment (Jupiter and Marion 2008), the key question is whether an antecedent submerged reef at Round Top "turned off" and became buried by heavy sedimentation or whether reef development never "turned on" due to chronically adverse conditions (Buddemeier and Hopley 1988).

As observed in prior studies (Alibert et al. 2003; McCulloch et al. 2003), coral $\mathrm{Ba} / \mathrm{Ca}$ was significantly related to river discharge (Table $3 b$ ), which is the main source of Ba to the nearshore (Hanor and Chan 1977). Ba transported by rivers rapidly desorbs from fine-grained terrestrial sediment within the low salinity $(0-5 \mathrm{ppt})$ zone and advects with the flood plumes into nearshore waters, where it is incorporated into coral aragonite in close proportion to its local abundance (McCulloch et al. 2003). 
Although Hacker (1988) estimated a two- to fourfold increase in sediment yield from the Pioneer catchment since European arrival, the majority of eroded terrestrial sediment may never reach coral reef communities: due to its unusual macrotidal configuration, much of the sediment is retained within the Pioneer River Estuary or along the adjoining foreshore. Ba may continue to desorb from sediment buried in the estuary and nearshore and be flushed seaward with flood tides (Carroll et al. 1993; Alibert et al. 2003). This process likely contributes to the elevated $\mathrm{Ba} / \mathrm{Ca}$ values that continue for several months following flood events (Fig. 6). The round shape of the Round Top Ba/Ca peaks contrasts strongly with the sharp $\mathrm{Ba} / \mathrm{Ca}$ peaks observed from inshore corals influenced by the Burdekin River (Sinclair and McCulloch 2004), which passes through virtually no estuary and discharges sediment directly into the marine environment (Hacker 1988).

While some fine sediment may still be transported with Pioneer flood plumes and have consequent effects on reef organisms (Fabricius 2005), Larcombe and Woolfe (1999) argue that turbidity is largely governed by local hydrodynamics and resuspension as opposed to sediment supply. Limited inner reef development between Mackay and Broad Sound (Fig. 1) has been previously attributed to elevated turbidity caused by high current speeds (up to $3 \mathrm{~m} \mathrm{~s}^{-1}$ ) associated with large (up to $10 \mathrm{~m}$ ) tidal ranges (Kleypas 1996). Frequent high tidal velocities create chronic turbidity from sediment resuspension, thus limiting maximum reef depth, while low mean water levels restrict upward reef growth (Kleypas 1996; Cooper et al. 2007). With a 6.4-m tidal range, Round Top Island would experience similar levels of sediment resuspension and a compressed zone for reef development, with bottom depths only $\sim 5-10 \mathrm{~m}$ below LAT. Like the reefs around the Northumberland Islands adjacent to Broad Sound described in Kleypas (1996) and van Woesik and Done (1997), the coral community at Round Top had greater numbers of turbidity tolerant species, such as encrusting Montipora spp. and foliaceous Turbinaria spp., with reduced overall dominance of more sensitive branching Acropora spp. The high turbidity may have additionally contributed to the lack of macroalgae as heavy sedimentation can maintain algal communities in arrested succession through negative effects on recruitment, survival, and growth of fleshy species (Umar et al. 1998). Similarly, Done et al. (2007) noted absence of macroalgae and Acropora at backreef location at Pandora Reef with high sedimentation rates and a high proportion of fine $(<63 \mu \mathrm{m})$ particles.

North of Broad Sound, which receives minimal river inputs, nearshore reef development may have also been limited by freshwater exposure. The coral luminescence records suggest that Round Top is chronically exposed to pulses of freshwater. Although there were significant differences in maximum - mean luminescence intensity in wet versus dry years, there was no significant relationship between peak luminescence and annual Pioneer River discharge. This is because, at only $5 \mathrm{~km}$ from the Pioneer River mouth, Round Top corals are influenced by strong tidal flux and show intense annual luminescent lines, even in years of low to moderate discharge. The combined luminescence and $\mathrm{Ba} / \mathrm{Ca}$ records therefore suggest that long-term, chronic (sub-annual) disturbance from both freshwater and elevated turbidity may have prevented historic reef development at Round Top by creating adverse conditions for major reef builders. The small colonies present had little cementation to the reef matrix and are therefore susceptible to mechanical damage which prevents reef accretion (van Woesik and Done 1997).

Group 2: Episodic, high-magnitude exposure

In contrast to the coral core records from Round Top Island that indicate a long-term, chronically stressful environment, both the Keswick Island luminescence and $\delta^{15} \mathrm{~N}$ time series show discrete, episodic exposure to terrestrial discharge. Of all three locations, Keswick corals showed the most significant difference in peak luminescence height (relative to mean luminescence intensity) in wet versus dry years. The longest core from Keswick Island (KIC: 19682004) had particularly bright luminescent lines in every major flood year during the record (1971, 1974, 1976, 1989, 1990, and 1991), with elevated peaks that sharply contrasted with luminescence resulting from seasonal differences in skeletal density (Fig. 5b).

In addition, Keswick coral skeletal nitrogen from two of the most extreme flood years (1974 and 1991) had elevated $\delta^{15} \mathrm{~N}$ values (12.24\%o and $13.62 \%$, respectively). These values are highly enriched over background seawater particulate organic matter (POM) $\delta^{15} \mathrm{~N}$. Wastewater from septic systems and untreated sewage, with $\delta^{15} \mathrm{~N}$ of dissolved inorganic nitrogen (DIN) typically above $10 \%$ (Heaton 1986), have been shown to enrich the $\delta^{15} \mathrm{~N}$ values in coral skeletons and other reef organisms (Risk and Erdmann 2000; Marion et al. 2005). However, Mackay has a secondary sewage treatment facility and mean $\delta^{15} \mathrm{~N}$ of POM sampled from the outflow was $3.0 \pm 0.2 \%$ (Marion 2007). Therefore, enrichment in flood years in the KI corals is more likely to reflect discharge of ${ }^{15} \mathrm{~N}$-enriched lower Pioneer River nitrogen sources $(\sim 9 \%$ ) combined with further fractionation $(+1-7 \%$ o associated with planktonic uptake of land-derived nitrogen and microbial remineralization of senescent plankton detrital matter (Waser et al. 1998; Marion 2007).

Extreme flood events have previously been related to large-scale death of coral assemblages in the southern GBR. The combination of massive flooding coinciding 
with peak spring tides in January 1918 is believed to have resulted in near total mortality of the innermost fringing reefs of the Whitsunday group (Rainford 1925). In the Keppel Islands following Cyclone Joy in late 1990, floodwaters from the Fitzroy River damaged corals to $1.3 \mathrm{~m}$ depth, causing epidermal cell death and bleaching predominantly in corals from the families Acroporidae and Pocilloporidae (van Woesik et al. 1995). In such cases, recovery of coral cover can be slow: DeVantier et al. (2006) reported low coral cover and species richness from reefs in the Northumberland Group and Keppel Islands surveyed in 1997 that were considered legacies from the 1990 death event.

During extreme, acute events, nearshore reefs adjacent to agricultural centers or waste disposal sources can be inundated with anthropogenic nutrients that may have direct and indirect effects on coral reef organisms (Fabricius 2005), with possible dramatic effects on coral community composition. For example, pulses of terrestrial nutrients are rapidly transformed into phytoplankton biomass that is advected offshore with the flood plumes (Furnas et al. 2005). Elevated nutrient concentrations are known to contribute to biologically mediated flocculation of sediments and organic matter (derived from phytoplankton blooms) into large, sticky aggregates (Fabricius and Wolanski 2000). As small coral reef organisms (e.g., coral recruits) are highly susceptible to smothering and consequent mortality from marine snow (Fabricius et al. 2003), acute exposure to flocculated particulate matter can skew population demographics and impede coral recovery by removing whole cohorts (Fabricius 2005). A recent modeling study concluded that the nutrient-enriching impact of rivers draining agricultural catchment of the GBR has extended $20-30 \mathrm{~km}$ further offshore since European arrival (Wooldridge et al. 2006). In the Mackay region, long-term coral $\delta^{15} \mathrm{~N}$ data show isotopic enrichment associated with flood years that has increased at a rate significantly correlated with regional increases in fertilizer consumption since the 1950s (Marion 2007). This change, in concert with repeat disturbance causing coral morality, may have had a strong, recent effect on the current coral community composition.

High cover of fleshy macroalgae was observed at all Keswick and St. Bees transect locations and appears to persist through time and seasons (S. Jupiter, pers. obs.). There is still considerable debate, however, regarding the significance of large stands of macroalgae on nearshore GBR reefs (DeVantier et al. 1998). Although fleshy macroalgae have been suggested to be indicators of eutrophication and subsequent reef degradation (Bell and Elmetri 1995), their presence is often a natural successional stage following disturbance that damages or kills coral tissue (Diaz-Pulido and McCook 2002). When recurrence intervals of disturbance are low, rapid radial extension $\left(>10 \mathrm{~cm} \mathrm{yr}^{-1}\right.$ ) of fast-growing coral genera such as Montipora and Acropora enable the colonies to overgrow algal holdfasts during senescent periods and recover dominance within the community (Done 1992). Macroalgal persistence, however, is likely due to complex, synergistic effects of increased disturbance frequency, increased nutrients and reduced herbivore abundance that will vary in importance by location (McCook 1999).

Because no data currently exist on herbivore abundance at Group 2, it is uncertain whether the initial cause of macroalgal dominance resulted from reduced herbivory (e.g., McManus et al. 2000), high frequency disturbance coupled with enhanced nutrient availability or a combination of the above. The disproportionate representation of acroporids and near absence of more robust taxa such as faviids and poritids appears to suggest that repeated disturbance caused major mortality at the site, while the coral core data indicate that the reefs have recently (within the past 16 years) been exposed to high volumes of freshwater carrying terrestrial nitrogen that did not historically reach the island (Marion 2007). In theory, 16 years should be ample time for coral recovery if there is adequate adult stock of fast growing acroporids (Done et al. 2007) and the reef suffers no further acute or chronic disturbance. Yet current numbers of acroporids may be too low to repopulate the reef, and the islands are geographically isolated (by both distance and prevailing currents) from their neighbors. The ability to recover may be further reduced if established fleshy macroalgal stands limit settlement of coral larvae (Kuffner et al. 2006) and exposure to nutrient-rich runoff reduces survivorship. Fabricius et al. (2005) suggested that declining water quality may have similarly slowed coral recovery at Russell and Normanby reefs, two inshore locations within the Wet Tropics region that had reduced coral cover since 1990 due to bleaching, crown-of-thorns (COTS), and a cyclone. In both locations, coral cover has either remained static or continued to decline even in the absence of further severe disturbance.

\section{Group 3: Episodic, low-magnitude exposure}

In contrast to the Group 2 reefs, the coral core records suggest that exposure to terrestrial discharge is highly attenuated and infrequent by $51 \mathrm{~km}$ offshore at Scawfell Island (Group 3). Although peak coral luminescence was correlated with Pioneer River discharge, the amplitude of the peaks was very low, suggesting the freshwater was considerably diluted during the flood years (1989, 1991) when plumes may have reached the reef. Alternatively, it is possible that the luminescent lines resulted from localized island runoff draining into Refuge Bay, produced by the same precipitation events causing runoff for the Pioneer 
River. A third bright luminescent line in 1983 is unlikely to be a response to freshwater runoff due to the low discharge volume from the Pioneer River. As anomalous luminescent lines have previously been associated with thin, highdensity stress bands in corals distant from terrestrial sources (Smithers and Woodroffe 2001), the intense line (visible in 1983 for all the cores analyzed in this study) may represent a regional response to El Niño-induced climate perturbations (Jupiter 2006).

The characteristics of $\mathrm{Ba} / \mathrm{Ca}$ and $\delta^{15} \mathrm{~N}$ records from Group 3 corals do not indicate strong exposure to Pioneer catchment sources. The generally low, but variable $\mathrm{Ba} / \mathrm{Ca}$ values $($ mean $=3.55 \mu \mathrm{mol} / \mathrm{mol}$ ) were similar to $\mathrm{Ba} / \mathrm{Ca}$ values from Davies Reef, approximately $70 \mathrm{~km}$ NNE from Townsville and out of reach of most river plumes (Alibert et al. 2003). Although there were large peaks in the record, they have no regular frequency and likely reflect heterogeneity within coral skeletal elements or incorporated organic material rather than a stronger, over-riding environmental signal (Allison 1996). Mean skeletal $\delta^{15} \mathrm{~N}$ values $(3.5 \%$ ) were similar to measurements of marine POM (Marion 2007) and Porites lobata tissue $\delta^{15} \mathrm{~N}$ (3.8\%o) measured from corals $40-50 \mathrm{~km}$ offshore from Townsville (Sammarco et al. 1999). Natural marine $\delta^{15} \mathrm{~N}$ values typically fall between $\sim 4$ and 6\% (Owens 1987), with localized variability depending on relative contributions of: $\mathrm{N}$-fixation, which depletes the $\delta^{15} \mathrm{~N}$ of the particulate nitrogen pool; remineralization by phytoplankton, resulting in $\delta^{15} \mathrm{~N}$ enrichment; and upwelling of deep-water nitrate, also resulting in $\delta^{15} \mathrm{~N}$ enrichment (Altabet 2006).

When evaluated together, the coral records support the conclusion that Scawfell Island is relatively free from the influence of the Pioneer catchment. It is therefore expected that Scawfell hard and soft coral abundance fluctuates in response to their relative susceptibility to bleaching, mechanical disturbance, predation, and disease. Mean live hard coral cover $(17.7 \pm 3.0 \%)$ was slightly lower than observed by van Woesik and Done (1997) on Cockermouth and Scawfell Islands' reefs (26.9\%), while dominance of acroporid corals was higher, possibly because the sampling was not as extensive as in the prior study. The belowaverage value compared with the average (33\%) of AIMS nearshore monitoring sites (Sweatman et al. 2007) may be due to competition for space with soft coral assemblages $(31.3 \pm 4.6 \%)$, which had the highest cover recorded from all locations. Episodic disturbance that causes hard coral decline can release octocorals from competition and increase their abundance (Fabricius 1998). For example, following massive bleaching and coral mortality in 1998 at Aldabra Atoll, Seychelles, soft corals of the genus Rhytisma opportunistically colonized newly available space (Stobart et al. 2005). While disturbance from tropical cyclones (eight over the record period noted in Fig. 2), bleaching (potentially in 1983 or 1998 during large SST anomalies), predation, or disease could have initiated a release of soft corals at Scawfell Island, it is unlikely to have been triggered by a flood-related event.

\section{Group 4: Relatively unexposed}

To date, there appear to be no prior surveys of reef condition or community structure at the three outermost reefs. Mean live hard coral cover at Derwent Island and the Kindemar reefs (23-29\%) was within the range of the highly variable values ( $\sim 10-70 \%$ median cover) observed by the Australian Institute of Marine Science's long-term monitoring surveys (1986-2005) of middle shelf reefs in the Pompey Sector (Sweatman et al. 2005). Even though the reef geomorphology varied among survey sites at each reef, the reefs clustered together largely due to similar high abundances of crustose coralline algae, which can indicate high wave energy conditions (Done 1982). All the middleshelf reefs in this region are likely to encounter high energy conditions from waves propagating through the Capricorn Channel (Kleypas and Hopley 1992).

Although there is no luminescence or geochemical data from corals at Group 4 reefs, it is unlikely that flood plumes from the Pioneer or adjacent rivers would travel this far across the shelf: Lough et al. (2002) found no visible luminescent lines from Credlin Reef $(\sim 50 \mathrm{~km}$ NNE of Derwent). However, variable effects of tropical cyclones, COTS outbreaks, and bleaching have been noted at nearby reefs in the Pompey sector (Sweatman et al. 2005). For example, Sweatman et al. (2005) noted declines in hard coral at Credlin Reef both following Cyclone Justin in 1997 and after the 2002 bleaching event, while significant coral mortality was associated with high numbers of COTS observed in 2001 on Southampton reef ( $\sim 40 \mathrm{~km} \mathrm{~N}$ of Little Kindemar). Yet without temporal monitoring data, long-term coral records or surveys of scarring on massive Porites to assess the timing of prior COTS outbreaks (DeVantier and Done 2007), we can say little about disturbance frequency or which particular disturbances may have affected community composition at Derwent on the Kindemar Reefs.

In summary, coral core records can provide insights into long-term environmental changes, in particular providing constraints on the frequency and intensity to which nearshore reefs are exposed to terrestrial runoff. By measuring multiple proxies that reflect different environmental parameters, logical links can be made between the structure of present day coral communities and how they may have responded to prior acute or chronic disturbance. The results from this study conducted along an inshore to offshore gradient of environmental change suggest several classes of response. Not surprisingly, reefs historically exposed to high levels of 
runoff and chronic turbidity may never have been capable of reef development. Intermediate locations that are episodically disturbed by pulses of river runoff enriched in anthropogenic nutrients may have reduced ability to recover, which can affect reef persistence if corals are replaced by macroalgae and if destructive processes (e.g., erosion) outweigh carbonate accretion (Done 1999). Finally, more distal reefs that are minimally exposed to terrestrial discharge likely have strong capacity for recovery from other types of documented disturbance (e.g., tropical cyclones, bleaching, COTS), given the current abundance of coral, however, this may be affected in the near future by global climate change. Given that multi-decadal environmental monitoring is nonexistent for most coral reef regions, long-lived coral records, as archives of environmental change, fill an important gap in assessing how modern reef assemblages were shaped by historical disturbance.

Acknowledgments Funding for this project was provided through an ARC Linkage grant (LP050896) to O. Hoegh-Guldberg and M. McCulloch, with significant contributions from the Mackay City Council, the Mackay Whitsunday Natural Resource Management Group and the Great Barrier Reef Marine Park Authority. Fieldwork was conducted aboard the Lara Star, operated by Warren and Barbara Hill, to whom we are very grateful. We thank Les Kinsley, Dave Mucciarone, and Eric Matson for laboratory assistance, and Janice Lough and Terry Done for helpful comments on the manuscript.

\section{References}

Alibert C, Kinsey L, Fallon SJ, McCulloch MT, Berkelmans R, McAllister F (2003) Source of trace element variability in Great Barrier Reef corals affected by the Burdekin flood plumes. Geochim Cosmochim Acta 67:231-246

Allison N (1996) Geochemical anomalies in coral skeletons and their possible implications for palaeoenvironmental analyses. Mar Chem 55:367-379

Altabet MA (2006) Isotopic tracers of the marine nitrogen cycle: past and present. In: Volkman JK (ed) Marine organic matter: biomarkers, isotopes and DNA. Springer, Berlin, pp 251-293

Barnes DJ, Taylor RB, Lough JM (2003) Measurement of luminescence in coral skeletons. J Exp Mar Biol Ecol 295:91-106

Beck JW, Edwards RL, Ito E, Taylor FW, Recy J, Rougerie F, Joannot P, Henin C (1992) Sea-surface temperature from coral skeletal strontium/calcium ratios. Science 257:644-647

Bell PRF, Elmetri I (1995) Ecological indicators of large-scale eutrophication in the Great Barrier Reef lagoon. Ambio 24:208-215

Bray JR, Curtis JT (1957) An ordination of the upland forest communities in southern Wisconsin. Ecol Monogr 27:325-349

Buddemeier RW, Hopley D (1988) Turn-ons and turn-offs: causes and mechanisms of the initiation and termination of coral reef growth. Proc 6th Int Coral Reef Symp 1:253-261

Carroll J, Falkner KK, Brown ET, Moore WS (1993) The role of the Ganges-Brahmaputra mixing zone in supplying barium and ${ }^{226} \mathrm{Ra}$ to the Bay of Bengal. Geochim Cosmochim Acta 57:2981-2990

Clarke KR, Warwick RM (2001) Change in marine communities: an approach to statistical analysis and interpretation, 2nd edn. Primer-e, Plymouth
Cohen J (1973) Eta-squared and partial eta-squared in fixed factor ANOVA designs. Educ Psychol Meas 33:107-112

Connell JH (1978) Diversity in tropical rain forests and coral reefs. Science 199:1302-1310

Cooper TF, Uthicke S, Humphrey C, Fabricius KE (2007) Gradients in water column nutrients, sediment parameters, irradiance and coral reef development in the Whitsunday Region, central Great Barrier Reef. Estuar Coast Shelf Sci 74:458-470

De'ath G, Moran P (1998) Factors affecting the behaviour of crownof-thorns starfish (Acanthaster planci) on the Great Barrier Reef. 2. Feeding preferences. J Exp Mar Biol Ecol 220:107-126

DeVantier LM, Done TJ (2007) Inferring past outbreaks of the crownof-thorns seastar from scar patterns on coral heads. In: Aronson $\mathrm{R}$ (ed) Geological approaches to coral reef ecology. Springer, New York, pp 85-125

DeVantier LM, De'ath G, Done TJ, Turak E (1998) Ecological assessment of a complex natural system: a case study from the Great Barrier Reef. Ecol Appl 8:480-496

DeVantier LM, De'ath G, Turak E, Done TJ, Fabricius KE (2006) Species richness and community structure of reef-building corals on the nearshore Great Barrier Reef. Coral Reefs 25:329-340

Diaz-Pulido G, McCook LJ (2002) The fate of bleached corals: patterns and dynamics of algal recruitment. Mar Ecol Prog Ser 232:115-128

Done TJ (1982) Patterns in the distribution of coral communities across the central Great Barrier Reef. Coral Reefs 1:95-107

Done TJ (1992) Phase shifts in coral reef communities and their ecological significance. Hydrobiologia 247:121-132

Done TJ (1999) Coral community adaptability to environmental change at the scales of regions, reefs and reef zones. Am Zool 39:66-79

Done TJ, Turak E, Wakeford M, DeVantier L, McDonald A, Fisk D (2007) Decadal changes in turbid-water coral communities at Pandora Reef: loss of resilience or too soon to tell? Coral Reefs 26:789-805

Fabricius KE (1998) Reef invasion by soft corals: which taxa and which habitats? In: Grenwood JG, Hall NJ (eds) Proceedings of the Australian Coral Reef Society 75th Anniversary Conference. School of Marine Science, University of Queensland, Brisbane, pp 77-90

Fabricius KE (2005) Effects of terrestrial runoff on the ecology of corals and coral reefs: review and synthesis. Mar Pollut Bull 50:125-146

Fabricius K, Wolanski E (2000) Rapid smothering of coral reef organisms by muddy marine snow. Estuar Coast Shelf Sci 50:115-120

Fabricius KE, Wild C, Wolanski E, Abele D (2003) Effects of transparent exopolymer particles and muddy terrigenous sediments on the survival of hard coral recruits. Estuar Coast Shelf Sci 57:613-621

Fabricius K, De'ath G, McCook L, Turak E, Williams DM (2005) Changes in algal, coral and fish assemblages along water quality gradients on the inshore Great Barrier Reef. Mar Pollut Bull 51:384-398

Fallon SJ, McCulloch MT, van Woesik R, Sinclair DJ (1999) Corals at their latitudinal limits: laser ablation trace element systematics in Porites from Shirigai Bay, Japan. Earth Planet Sci Lett 172:221-238

Furnas M, Mitchell A, Skuza M, Brodie J (2005) In the other 90\%: phytoplankton responses to enhanced nutrient availability in the Great Barrier Reef Lagoon. Mar Pollut Bull 51:253-265

Hacker JLF (1988) Rapid accumulation of fluvially derived sands and gravels in a tropical macrotidal estuary: the Pioneer River at Mackay, North Queensland, Australia. Sediment Geol 57:299_ 315 
Hanor JS, Chan L-H (1977) Non-conservative behavior of barium during mixing of Mississippi River and Gulf of Mexico waters. Earth Planet Sci Lett 37:242-250

Heaton $\mathrm{T}$ (1986) Isotopic studies of nitrogen pollution in the hydrosphere and atmosphere: a review. Chem Geol 59:87-102

Hoegh-Guldberg O, Mumby PJ, Hooten AJ, Steneck RS, Greenfield P, Gomez E, Harvell DR, Sale PF, Edwards AJ, Caldeira K, Knowlton N, Eakin CM, Iglesias-Prieto R, Muthiga N, Bradbury RH, Dubi A, Hatziolos ME (2007) Coral reefs under rapid climate change and ocean acidification. Science 318:1737-1742

Hopley D (1984) The Holocene 'high energy window' on the central Great Barrier Reef. In: Thom BG (ed) Coastal geomorphology in Australia. Academic Press, Canberra, pp 135-150

Hopley D, Parnell KE, Isdale PJ (1989) The Great Barrier Reef Marine Park: dimensions and regional patterns. Aust Geogr Stud 27:47-66

Hughes TP (1989) Community structure and diversity of coral reefs: the role of history. Ecology 70:275-279

Hughes TP (1994) Catastrophes, phase shifts, and large-scale degradation of a Caribbean coral reef. Science 265:1547-1551

Isdale P (1984) Fluorescent bands in massive corals record centuries of coastal rainfall. Nature 310:578-579

Jupiter SD (2006) From cane to coral reefs: ecosystems linkages and downstream responses to land use intensification. Ph.D. thesis, University of California, Santa Cruz, p 300

Jupiter SD, Marion GS (2008) Changes in forest area along stream networks in an agricultural catchment of the Great Barrier Reef lagoon. Environ Manage 42:66-79

King B, McAllister F, Wolanski E, Done T, Spagnol S (2001) River plume dynamics in the central Great Barrier Reef. In: Wolanksi E (ed) Oceanographic processes of coral reefs: physical and biological links in the Great Barrier Reef. CRC Press, Boca Raton, pp 145-160

Kleypas JA (1996) Coral reef development under naturally turbid conditions: fringing reefs near Broad Sound, Australia. Coral Reefs 15:153-167

Kleypas JA, Hopley D (1992) Reef development across a broad continental shelf, southern Great Barrier Reef, Australia. Proc $7^{\text {th }}$ Int Coral Reef Symp 2:1129-1141

Kohler KE, Gill SM (2006) Coral Point Count with Excel extensions (CPCe): a visual basic program for the determination of coral and substrate coverage using random point count methodology. Comput Geosci 32:1259-1269

Kuffner IB, Walters LJ, Beccero MA, Paul VJ, Ritson-Williams R, Beach KS (2006) Inhibition of coral recruitment by macroalgae and cyanobacteria. Mar Ecol Prog Ser 323:107-117

Larcombe P, Woolfe KJ (1999) Increased sediment supply to the Great Barrier Reef will not increase sediment accumulation at most coral reefs. Coral Reefs 18:163-169

Lough JM (1994) Climate variation and El Nino-Southern Oscillation events on the Great Barrier Reef: 1958 to 1987. Coral Reefs 13:181-195

Lough JM (2004) A strategy to improve the contribution of coral data to high-resolution paleoclimatology. Palaeogeogr Palaeoclimatol Palaeoecol 204:115-143

Lough JM, Barnes DJ, McAllister FA (2002) Luminescent lines in corals from the Great Barrier Reef provide spatial and temporal records of reefs affected by land runoff. Coral Reefs 21:333-343

Marion GS (2007) The nitrogen isotopic composition of the organic matrices of coral skeleton: A proxy for historical nitrogen provenance in tropical coastal oceans. Ph.D. thesis, University of Queensland, p 190

Marion GS, Dunbar RB, Mucciarone DA, Kremer JN, Lansing JS, Arthawinguna A (2005) Coral skeletal $\delta^{15} \mathrm{~N}$ reveals isotopic traces of an agricultural revolution. Mar Pollut Bull 50:931-944
Marshall PA, Baird AH (2000) Bleaching of corals on the Great Barrier Reef: differential susceptibilities among taxa. Coral Reefs 19:155-163

McCook LJ (1999) Macroalgae, nutrients and phase shifts on coral reefs: scientific issues and management consequences for the Great Barrier Reef. Coral Reefs 18:357-367

McCulloch M, Fallon S, Wyndham T, Hendy E, Lough J, Barnes D (2003) Coral record of increased sediment flux to the inner Great Barrier Reef since European settlement. Nature 421:727-730

McManus JW, Menez LAB, Reyes KNK, Vergara SG, Ablan MC (2000) Coral reef fishing and coral-algal phase shifts: Implications for global reef status. ICES J Mar Sci 57:572-578

Middleburg JJ, Nieuwenhuize J (2001) Nitrogen isotope tracing of dissolved inorganic nitrogen behaviour in tidal estuaries. Estuar Coast Shelf Sci 53:385-391

Neil DT, Orpin AR, Ridd PV, Yu B (2002) Sediment yield and impacts from river catchments to the Great Barrier Reef lagoon. Mar Freshw Res 53:733-752

Nystrom M, Folke C, Moberg F (2000) Coral reef disturbance and resilience in a human-dominated environment. Trends Ecol Evol 15:413-417

Ostrander GK, Meyer Armstrong K, Knobbe ET, Gerace D, Scully EP (2000) Rapid transition in the structure of a coral reef community: The effects of coral bleaching and physical disturbance. Proc Natl Acad Sci USA 97:5297-5302

Owens N (1987) Natural variations in $15 \mathrm{~N}$ in the marine environment. Adv Mar Biol 24:389-451

Pulsford JS (1996) Historical nutrient usage in coastal Queensland river catchments adjacent to the Great Barrier Reef Marine Park. Great Barrier Reef Marine Park Authority Research Publication No. 40, Townsville, Australia p. 63

Rainford EH (1925) Destruction of the Whitsunday Group fringing reefs. Aust Mus Mag 2:175-177

Rayment GE, Neil DT (1997) Sources of material in river discharge. Proceedings of The Great Barrier Reef: science, use and management a national conference. Great Barrier Reef Marine Park Authority, Townsville, 1:42-58

Risk MJ, Erdmann MV (2000) Isotopic composition of nitrogen in stomatopd (Crustacea) tissues as an indicator of human sewage impacts on Indonesian coral reefs. Mar Pollut Bull 40:50-58

Sammarco PW, Risk MJ, Schwarcz HP, Heikoop JM (1999) Cross continental shelf trends in coral $\delta^{15} \mathrm{~N}$ on the Great Barrier Reef: further consideration of the reef nutrient paradox. Mar Ecol Prog Ser 180:131-138

Sinclair DJ, McCulloch MT (2004) Corals record low mobile barium concentrations in the Burdekin River during the 1974 flood: evidence for limited Ba supply to rivers? Palaeogeogr Palaeoclimatol Palaeoecol 214:155-174

Sinclair DJ, Kinsey LPJ, McCulloch MT (1998) High resolution analysis of trace elements in corals by laser ablation ICP-MS. Geochim Cosmochim Acta 62:1889-1901

Smithers SG, Woodroffe CD (2001) Coral microatolls and $20^{\text {th }}$ century sea level in the eastern Indian Ocean. Earth Planet Sci Lett 191:173-184

Stobart B, Teleki K, Buckley R, Downing N, Callow M (2005) Coral recovery at Aldabra Atoll, Seychelles: five years after the 1998 bleaching event. Philos Trans R Soc Lond A 363:251-255

Sweatman H, Thompson A, Delean S, Davidson J, Neale S (2007) Status of near-shore reefs of the Great Barrier Reef 2004. Marine and Tropical Research Facility Research Report Series, Reef and Rainforest Research Centre Limited, Cairns

Sweatman H, Burgess S, Cheal A, Coleman G, Delean S, Emslie M, McDonald A, Miller I, Osborne K, Thompson A (2005) Longterm monitoring of the Great Barrier Reef. Australian Institute of Marine Sciences, Townsville 
Umar MJ, McCook LJ, Price IR (1998) Effects of sediment deposition on the seaweed Sargassum on a fringing coral reef. Coral Reefs 17:169-177

van Woesik R, Done TJ (1997) Coral communities and reef growth in the southern Great Barrier Reef. Coral Reefs 16:103-115

van Woesik R, DeVantier LM, Glazebrook JS (1995) Effects of Cyclone 'Joy' on nearshore coral communities of the Great Barrier Reef. Mar Ecol Prog Ser 128

van Woesik R, Tomascik T, Blake S (1999) Coral assemblages and physico-chemical characteristics of the Whitsunday Islands: evidence of recent community changes. Mar Freshw Res 50:427-440

Waser NAD, Harrison PL, Nielsen B, Calvert SE, Turpin DH (1998) Nitrogen isotope fractionation during the uptake and assimilation of nitrate, nitrite, ammonium, and urea by a marine diatom. Limnol Oceanogr 43:215-224

Wooldridge S, Brodie J, Furnas M (2006) Exposure of inner-shelf reefs to nutrient enriched runoff entering the Great Barrier Reef Lagoon: Post-European changes and the design of water quality targets. Mar Pollut Bull 52:1467-1479 